\title{
Perennial ryegrass regrowth after defoliation - physiological and molecular changes
}

\author{
J.M. LEE ${ }^{1}$, D.J. DONAGHY², P. SATHISH ${ }^{3}$ and J.R. ROCHE ${ }^{1}$ \\ ${ }^{I}$ DairyNZ Ltd., Private Bag 3221, Hamilton 3240 \\ ${ }^{2}$ University of Tasmania, PO Box 3523, Burnie, Tasmania 7320, Australia \\ ${ }^{3}$ Pastoral Genomics, c/o ViaLactia Biosciences Ltd., PO Box 109185, Auckland 1149 \\ julia.lee@dairynz.co.nz
}

\begin{abstract}
Many aspects of plant growth and physiology following defoliation have been investigated in perennial ryegrass (Lolium perenne). The changes, however, have rarely been characterised at a molecular (gene) level. Perennial ryegrass plots were defoliated at the 3-leaf stage to $1600 \mathrm{~kg} \mathrm{DM} / \mathrm{ha}$ (recommended grazing practice) and throughout the subsequent regrowth cycle, pasture mass, water-soluble carbohydrate (WSC) content and expression of carbon metabolism genes were determined. Plots accumulated $1900 \mathrm{~kg} \mathrm{DM} /$ ha, $45 \%$ of this between the 2- and 3-leaf stages of regrowth. Following defoliation, stubble WSC content declined $(\mathrm{P}<0.001)$ until the first new leaf had emerged, with replenishment occurring during emergence of the second new leaf. In stubble tissue, expression of the fructan degradation gene was greatest immediately after defoliation $(\mathrm{P}<0.001)$, while expression of a fructan synthesis gene was greatest following emergence of the first leaf $(P<0.05)$. Throughout regrowth, expression of photosynthesis genes increased $(\mathrm{P}<0.05)$ in leaf tissue, peaking at the 2-leaf stage of regrowth. These data indicate how perennial ryegrass plants alter their physiological processes following defoliation to survive and grow, and support recommendations for rotation lengths that are longer than the time taken to reach the 2-leaf stage of regrowth. Understanding how defoliation affects gene expression in perennial ryegrass could influence future plant breeding outcomes.
\end{abstract}

Keywords: rotation length, leaf stage, water-soluble carbohydrate, fructan, photosynthesis, gene expression

\section{Introduction}

Perennial ryegrass (Lolium perenne) is the most important pasture grass in New Zealand agriculture, providing the major supply of nutrients for grazing ruminants (Kemp et al. 2000). The popularity of perennial ryegrass is partly due to its ability to regrow rapidly after grazing or cutting, an event which causes dramatic changes to the plant. Defoliation removes photosynthetically active leaf tissue from plants, reducing or preventing photosynthesis, depending on the proportion removed. The supply of energy from photosynthesis is, therefore, generally insufficient to meet the plant's demands for subsequent growth of new leaves and respiration. To provide this energy, watersoluble carbohydrate (WSC; includes glucose, fructose, sucrose and fructans) reserves stored towards the base of the plants tillers (stubble) are mobilised (Donaghy \& Fulkerson 1997; Morvan-Bertrand et al. 2001). The mobilisation period or degradation of reserves generally lasts until the tillers have regrown about one full new leaf ( 1-leaf stage of regrowth; Fulkerson \& Donaghy 2001; Prud'homme et al. 1992). The tiller then has adequate leaf area and photosynthetic capacity to meet the energy requirements for maintenance and growth (Fulkerson \& Donaghy 2001), and can start to replenish its WSC reserves.

Profiling gene expression helps understand the complex biological processes affected by defoliation. Inside plant cells, genes are encoded in long DNA strands. During gene expression, information encoded in a particular DNA segment (or gene) is converted into a functional product (e.g. a protein). This process begins with the copying of the DNA sequence by the RNA polymerase enzyme to produce a complementary messenger RNA (mRNA). The most common method of profiling gene expression is reverse transcriptionquantitative polymerase chain reaction or RT-qPCR (Bustin 2000). RT-qPCR calculates the number of copies (or abundance) of a particular mRNA gene transcript in a sample. This indicates whether a certain biological process was occurring in the plant at the time the sample was taken, and at what rate the process was occurring.

In a previous paper (Lee et al. 2009) we reported on the effect of grazing frequency and severity on pasture yield, quality and WSC reserves. This paper adds to the published information by describing changes in gene expression following defoliation and correlating those changes with observed growth and physiological changes. This approach, while adding knowledge on how defoliation affects gene expression in perennial ryegrass pastures, could also impact on future plant breeding objectives aimed at improving pasture growth and persistence on-farm. 


\section{Methods}

\section{Experimental design}

The study was conducted at DairyNZ's Lye Farm near Hamilton ( $37^{\circ} 47^{\prime} \mathrm{S} 175^{\circ} 19^{\prime} \mathrm{E}$; elevation $40 \mathrm{~m}$ a.s.l.). In May 2007, nine plots (each 2 × 3 m) were laid out in newly-mown perennial ryegrass (cv. 'Bronsyn') dominant pasture. Plots were defoliated to about $1600 \mathrm{~kg} \mathrm{DM} / \mathrm{ha}$ (40 mm residual stubble height; recommended year-round grazing practice equating to approximately 8 'clicks' on the rising platemeter; DairyNZ 2008) using a rotary lawnmower when, on average, three new leaves had emerged on perennial ryegrass tillers. This resulted in defoliations in late June (covariate harvest) and again in late August.

\section{Leaf regrowth stage}

Each leaf regrowth stage was defined as the time taken for one new leaf per vegetative ryegrass tiller to fully emerge following defoliation. Following the late August harvest, leaf regrowth stage was measured weekly on 10 randomly selected tillers per plot using the method of Donaghy (1998).

\section{Pasture mass}

The pattern of pasture growth through time is described in this paper as Lee et al. (2009) only reports on yield at the 3-leaf stage. Compressed pasture height was measured on each plot ( $\mathrm{n}=10$ measurements/ plot), immediately after the late August harvest, and at each subsequent leaf regrowth stage, using a rising platemeter (RPM) with an electronic counter (Farmworks, Palmerston North, New Zealand). The average values were converted to pasture mass using a regression equation derived from calibration cuts from June to September. Briefly, on adjacent and similar swards over 3 years, pasture samples representative of a range of pasture masses were cut to ground level within square quadrats $\left(0.12 \mathrm{~m}^{2}\right)$ following RPM height determination. Samples were washed to remove soil and dried at $95^{\circ} \mathrm{C}$ for $48 \mathrm{~h}$. Data were used to develop a regression equation relating compressed pasture height $(\mathrm{mm})$ to pasture mass $(\mathrm{kg} \mathrm{DM} / \mathrm{ha})$ as follows:

Pasture mass $=28.9 \times$ compressed pasture height + $799\left(\mathrm{R}^{2}=0.74 ; \mathrm{n}=1640\right)$.

\section{Stubble WSC content}

Following the late August defoliation, 60 mature perennial ryegrass tillers (including roots) were harvested at random from each plot immediately before defoliation and at each subsequent leaf regrowth stage (1-, 2- and 3-leaf). Harvests were performed $3 \mathrm{~h}$ after sunrise to limit diurnal variation in WSC concentrations. After harvesting, samples were stored on ice until roots were removed from the tiller bases and tillers cut to
$40 \mathrm{~mm}$. Stubble samples (leaf sheaths plus enclosed elongating leaf bases) were then frozen at $-20^{\circ} \mathrm{C}$ before freeze-drying. Once dried, samples were weighed, ground to pass through a $1 \mathrm{~mm}$ sieve and analysed for WSC (Technicon Industrial Method number 30273A; derived from the method outlined by Smith 1969). Total stubble WSC content, a better indicator for regrowth potential than concentration (Donaghy \& Fulkerson 1998), was calculated by multiplying WSC concentration by the average dry weight of each stubble sample. The WSC data presented here are a subset of those presented by Lee et al. (2009).

\section{Gene expression}

At midday on the day following the late August defoliation, and at each subsequent leaf regrowth stage, 20 ryegrass tillers were harvested to ground level from different plants within each plot. Tissues were immediately frozen in liquid nitrogen, transported in dry ice and stored at $-80^{\circ} \mathrm{C}$. Leaf $(>40 \mathrm{~mm}$ from ground level) and stubble $(<40 \mathrm{~mm})$ tissues were separated and ground in liquid nitrogen. DNase I-treated total RNA was extracted using the RNeasy Plant Mini Kit (Qiagen, Hilden, Germany) and mRNA was isolated from the total RNA using Dynabeads ${ }^{\circledR}$ Oligo $(\mathrm{dT})_{25}$ (Invitrogen Dynal AS, Oslo, Norway). The mRNA (10 ng) was reverse transcribed using the Transcriptor First Strand cDNA Synthesis Kit (Roche Diagnostics, Mannheim, Germany) with anchored-oligo (dT) $)_{18}$ primers in total reaction volumes of $20 \mu 1$.

Four target genes involved in photosynthesis and fructan degradation and synthesis were selected. The key genes involved in photosynthesis were $r b c S$, which encodes for the small subunit of the ribulose 1,5-bisphosphate carboxylase/oxygenase (Rubisco) enzyme and $l h c b$, which encodes for a light harvesting chlorophyll $a / b$ binding protein. The fructan degradation and synthesis genes (feh and l-sst, respectively) encoded for the fructan exohydrolase (FEH) and the sucrose:sucrose 1-fructosyltranferase (1SST) enzymes, respectively. FEH is the only identified enzyme that degrades fructans (Chalmers et al. 2005), while 1-SST is one of two main enzymes in the proposed fructan synthesis pathway and is considered to be the enzyme determining the rate of synthesis (Nagaraj et al. 2004).

Primer pairs for the four genes were designed using Primer3 (http://primer3.sourceforge.net/; Rozen \& Skaletsky 2000) and ordered from a commercial supplier (Invitrogen, Auckland, New Zealand). Forward and reverse primer pairs were ATATCACCTGGGTCGAGGAA and CCAACGGCGAATAAAGAAAC for $r b c S, \quad$ GCCGACAACTTCATTTCTGA and 
TGAGAAATAACCACAAACAGCA

$l h c b, \quad$ CCTCTGACAACATGGAGGAG

for AAGCCTCCATAKGCTGGTGT for and CCAAGTTTAGCTCGTGTTGC and feh and TATTGTACGATCCCCATCCA for 1-sst, respectively.

Gene copy numbers were quantified for the target genes using RT-qPCR. The RT-qPCR were performed in 384-well plates with a LightCycler ${ }^{\circledR} 480$ real-time PCR instrument (Roche Diagnostics) using the LightCycler ${ }^{\mathbb{B}}$ 480 SYBR Green I Master kit. Each reaction contained $5 \mu 1$ of $2 x$ SYBR Green I Master mix, $2 \mu 1$ water, $2 \mu 1$ of 100 -fold diluted cDNA, and $0.5 \mu 1$ of each of the 10 $\mu \mathrm{M}$ forward and reverse gene-specific primers in a final volume of $10 \mu \mathrm{l}$. All reaction set-ups were performed using the epMotion ${ }^{\circledR}$ 5075LH automated liquid handling system (Eppendorf, Hamburg, Germany). Reactions were incubated at $95^{\circ} \mathrm{C}$ for 5 minutes to activate the FastStart Taq DNA polymerase, followed by 45 cycles at $95^{\circ} \mathrm{C}$ for 10 seconds, $60^{\circ} \mathrm{C}$ for 10 seconds and $72^{\circ} \mathrm{C}$ for 8 seconds. The specificity of the PCR reaction was confirmed with a heat dissociation protocol (from 60 to $95^{\circ} \mathrm{C}$ ) following the final PCR cycle.

Relative abundance or expression of each target gene was calculated by:

Relative gene abundance $=\frac{(\mathrm{T} / \mathrm{R} 1 \times \mathrm{T} / \mathrm{R} 2)^{0.5}}{(\mathrm{C} / \mathrm{R} 1 \times \mathrm{C} / \mathrm{R} 2)^{0.5}}$

This formula provides an efficiency-corrected relative quantification, normalised to a calibrator sample (either leaf or stubble at the 3-leaf stage), where $\mathrm{T}$ is the concentration of the target gene in a particular sample, R1 and R2 are the concentrations of the first and second validated reference genes (eukaryotic elongation factor $1 \alpha$ and YT521-B-like protein family protein, respectively; Lee et al. 2010b) in either a particular sample or the calibrator sample and $\mathrm{C}$ is the concentration of the target gene in the calibrator sample.

\section{Statistical analyses}

All data were analysed in GenStat (VSN International Ltd. 2008) using the AREPMEASURES procedure which produces an analysis of variance (ANOVA) for repeated measures with Greenhouse-Geisser adjustment. The relative abundance of each gene was $\log _{10}$-transformed before ANOVA. Following statistical analyses, averages for each treatment were backtransformed.

\section{Results}

\section{Growth and physiological changes after defoliation}

Following defoliation in late August, plots reached the 1-, 2- and 3-leaf stages of regrowth 17, 32 and 46 days after defoliation, respectively. During the 46 days, plots accumulated $1900 \mathrm{~kg} \mathrm{DM} / \mathrm{ha}$ (Fig. 1a). Between each leaf stage, pasture mass increased significantly
$(\mathrm{P}<0.001)$, with $290 \mathrm{~kg} \mathrm{DM} / \mathrm{ha}$ accumulated between defoliation and the 1-leaf stage, $755 \mathrm{~kg} \mathrm{DM} /$ ha between the 1- and 2-leaf stages and $855 \mathrm{~kg} \mathrm{DM} /$ ha between the 2 - and 3-leaf stages $(15,40$ and $45 \%$ of the total pasture accumulated, respectively).

The WSC reserves stored in the plant stubble declined $(\mathrm{P}<0.001)$ following defoliation (Fig. 1b). At the 2and 3-leaf stages, stubble WSC content had increased $(\mathrm{P}<0.001)$ compared to the 1-leaf stage; however, WSC reserves were still not fully replenished $(\mathrm{P}<0.001)$ to

Figure 1 Pasture mass (a) and stubble water-soluble carbohydrate (WSC) content (b) of perennial ryegrass dominant plots defoliated at the 3-leaf stage of regrowth to $1600 \mathrm{~kg} \mathrm{DM} / \mathrm{ha}$ and regrown till the 3-leaf stage. Error bars indicate the average standard error of the difference between leaf regrowth stages.

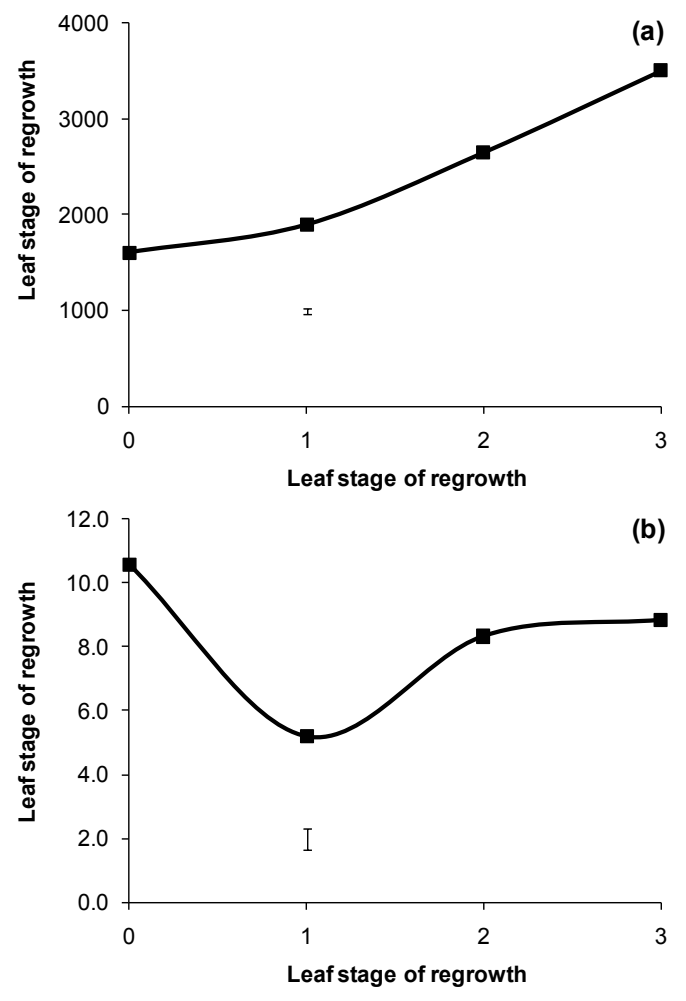

pre-defoliation levels.

\section{Molecular changes after defoliation}

Throughout the regrowth cycle, expression of the two key photosynthesis genes increased $(\mathrm{P}<0.05)$ in leaf tissue, peaking at the 2-leaf stage of regrowth (Fig. 2a \& 2b). In stubble tissue, expression of the fructan degradation gene, $f e h$, was greatest on the day after defoliation $(\mathrm{P}<0.001$; Fig. 3a). Following 
Figure 2 Expression levels of key photosynthesis genes, one encoding the small subunit of Rubisco ( $r b c S$; a) and the other, light harvesting chlorophyll $a / b$ binding proteins (Ihcb; b). Expression levels were measured in the leaf tissue of perennial ryegrass tillers defoliated at the 3-leaf stage to $1600 \mathrm{~kg}$ $\mathrm{DM} / \mathrm{ha}$, then regrown to the 3-leaf stage. Error bars indicate the average standard error of the difference between leaf regrowth stages.
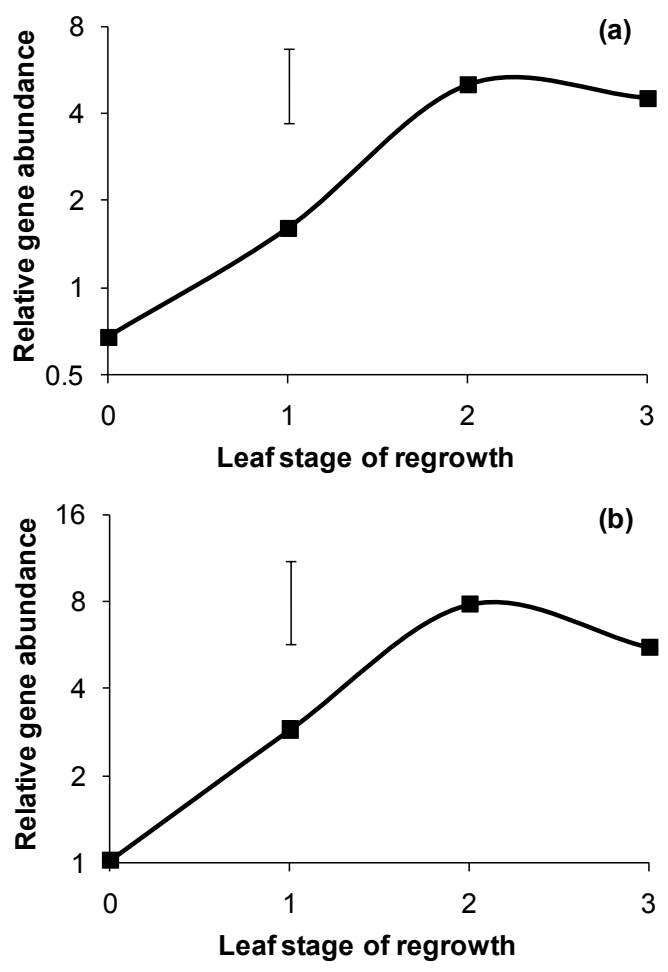

this, expression of feh declined, with no significant differences $(P>0.1)$ measured between the 1 - and 3-leaf stages. Expression of the fructan synthesis gene, 1 -sst, in stubble tissue increased following defoliation, peaking following emergence of the first new leaf $(\mathrm{P}<0.05)$, before declining (Fig. 3b).

\section{Discussion}

Following defoliation pasture growth rate follows a sigmoidal curve, which can be divided into three phases (Brougham 1957; Parsons \& Chapman 2000; Parsons \& Penning 1988). Immediately after defoliation, the growth rate is slow (the lag phase), increasing exponentially until a constant maximum rate is reached (the linear phase). During the third phase, growth rates continue unabated, however, rates of senescence begin to increase (i.e. net growth rates decline) until there is no further increase in pasture mass (ceiling yield). Results from the current study were consistent with
Figure 3 Expression levels of (a) a fructan degradation gene (fructan exohydrolase; feh) and (b) a fructan synthesis gene (sucrose:sucrose 1-fructosyltransferase; 1-sst) in the stubble of perennial ryegrass tillers defoliated at the 3-leaf stage to $1600 \mathrm{~kg} \mathrm{DM} / \mathrm{ha}$, then regrown to the 3-leaf stage. Error bars indicate the average standard error of the difference between leaf regrowth stages.
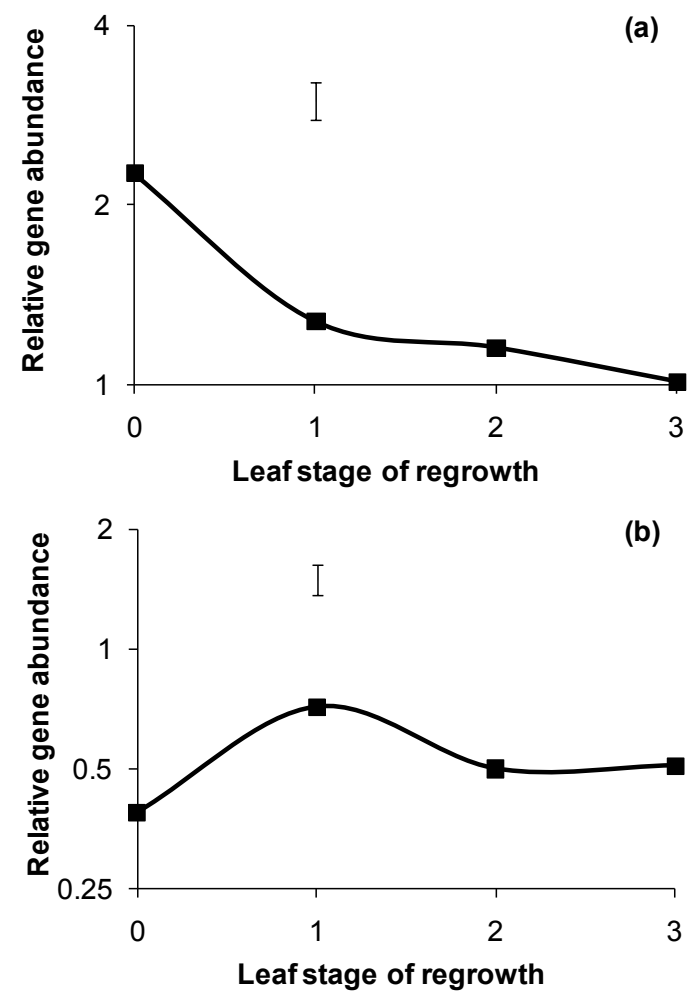

the first two phases of growth. Growth rates between defoliation and the 1-leaf stage were slow, averaging $17 \mathrm{~kg} \mathrm{DM} / \mathrm{ha} /$ day, compared with those between the 1- and 2-leaf stages, and the 2- and 3-leaf stages which averaged 50 and $61 \mathrm{~kg} \mathrm{DM} /$ ha/day, respectively. Previous research indicates that senescence begins around the 3.5- to 4-leaf stage of regrowth (Fulkerson \& Slack 1994; Robson 1973); therefore, a decline in net growth rate would not be expected to occur until after that stage.

One reason why growth rates are slower immediately following defoliation is that plants are reliant on stored WSC reserves to provide energy for regrowth (Donaghy \& Fulkerson 1997; Morvan-Bertrand et al. 2001). The period of sole reliance on WSC reserves usually only lasts 2 to 3 days (De Visser et al. 1997), after which, photosynthesis becomes the main carbon source. Eventually the carbon supply from photosynthesis becomes sufficient to provide enough energy for regrowth, as well as replenish reserves (Fulkerson \& Donaghy 2001; Prud'homme et al. 1992). The well- 
documented 'U-shaped' pattern of WSC depletion and replenishment was observed in the current study, with the lowest point measured at the 1-leaf stage of regrowth, followed by WSC replenishment between the 1- and 2-leaf stages. Previous studies have recorded the lowest point between 2 and 13 days post-defoliation, depending on nitrogen supply, temperature and cultivar (Davies 1965; Morvan-Bertrand et al. 1999), therefore, it is possible in the current study that the lowest point occurred before the 1-leaf stage measurement.

The pattern of depletion and replenishment has also been observed in perennial ryegrass leaf blades (Rasmussen et al. 2009); WSC concentrations in the leaves of five cultivars grown at $20 / 10^{\circ} \mathrm{C}$ (day/ night temperature) declined during the first 3 days post-defoliation before increasing, while at $10 / 10^{\circ} \mathrm{C}$ WSC concentrations declined later ( 6 days) and to a lesser extent. This indicates that WSC are mobilised from residual leaf blades as well as stubble to support regrowth immediately following defoliation, and that at lower temperatures there is less demand for carbon, likely due to slower plant growth.

The pattern of WSC depletion and replenishment is correlated with root and tiller growth as well as regrowth of new leaves. For grazed pasture plants to survive, it is logical that regrowth of the photosynthetic leaf canopy should take priority over root growth and tiller initiation and development. Donaghy \& Fulkerson (1998) demonstrated that root growth and tillering ceased after defoliation, with available WSC allocated to growth of new leaves. Root growth recommenced around the 1-leaf stage, while tiller initiation resumed around the time of WSC replenishment, which in the current study was around the 2-leaf stage. This means that defoliation of pastures before they reach the 2-leaf stage will reduce tiller initiation and thus pasture persistence.

The patterns of pasture growth and photosynthesis gene expression were similar in the current study. Like the growth curve, expression of key photosynthesis genes, $r b c S$ and $l h c b$, increased following defoliation until the 2-leaf stage. This provided evidence of increasing photosynthesis throughout regrowth which is in agreement with Parsons \& Penning's (1988) observations that canopy photosynthesis increased following defoliation in spring, summer and autumn, with daily rates increasing through till the 3-leaf stage in spring, and peaking around the 2-leaf stage in summer and autumn.

There was also good correlation between WSC reserves and fructan metabolism genes. Logically, expression of numerous genes involved in the utilisation of reserves increase during mobilisation and decrease during replenishment (Koch 1996). In perennial ryegrass, fructans make up the largest proportion of stored WSC, and are degraded by $\mathrm{FEH}$ to provide carbon (sucrose) for regrowth (Chalmers et al. 2005). The gene encoding the FEH enzyme, feh, had greatest expression on the day after defoliation indicating greater fructan degradation. This was substantiated by the decline in WSC after defoliation (Fig. 2b). During WSC replenishment, expression of feh was reduced. Conversely, expression of the fructan synthesis gene 1-sst was greater at the 1-leaf stage of regrowth than the day after defoliation, indicating WSC replenishment had begun.

Gene expression techniques are becoming increasingly important in agriculture as attempts are made to increase resource use efficiency, stress and disease tolerance and pasture yield. These techniques give greater understanding of how plants respond to external stimuli, for example grazing frequency (Lee et al. 2010a), information that can be used for plant breeding in the future.

\section{Practical implications}

Knowledge of plant growth, physiology and gene expression has contributed to the current grazing management recommendations that perennial ryegrass pastures should be grazed between the 2- and 3-leaf stages of regrowth to maximise growth and persistence. Before plants have regrown two full new leaves, rates of photosynthesis (and therefore growth) have not reached their maximum, WSC reserves have not been fully replenished and new tiller growth has not resumed. Grazing pastures before the 2-leaf stage, therefore, depletes WSC reserves, and through time reduces pasture growth, tiller density and pasture persistence (Donaghy 1998; Fulkerson \& Donaghy 2001; Turner et al. 2006). Grazing swards after the 3-leaf stage reduces tillering due to decreased light penetration into the pasture and wastes some of the grown pasture as it senesces, providing a lower quality, more fibrous feed (more stem and dead matter) (Fulkerson \& Donaghy 2001; Fulkerson \& Slack 1994; Grant et al. 1981).

\section{ACKNOWLEDGEMENTS}

We thank Barbara Dow for her statistical expertise and Pastoral Genomics, ViaLactia Biosciences and Roche Diagnostics for providing equipment and facilities. This study was funded by DairyNZ Inc., the Foundation for Research, Science and Technology, the T.R. Ellett Agricultural Research Trust and a Tasmanian Graduate Research Scholarship from the University of Tasmania awarded to the senior author.

\section{REFERENCES}

Brougham, R.W. 1957. Pasture growth rate studies in 
relation to grazing management. Proceedings of the New Zealand Society of Animal Production 17: 4655.

Bustin, S.A. 2000. Absolute quantification of mRNA using real-time reverse transcription polymerase chain reaction assays. Journal of Molecular Endocrinology 25: 169-193.

Chalmers, J.; Lidgett, A.; Cummings, N.; Cao, Y.; Forster, J.; Spangenberg, G. 2005. Molecular genetics of fructan metabolism in perennial ryegrass. Plant Biotechnology Journal 3: 459-474.

DairyNZ 2008. Farmfact 1-2 Principles of grazing management DairyNZ, Hamilton.

Davies, A. 1965. Carbohydrate levels and regrowth in perennial ryegrass. Journal of Agricultural Science 65: 213-221.

De Visser, R.; Vianden, H.; Schnyder, H. 1997. Kinetics and relative significance of remobilized and current $\mathrm{C}$ and $\mathrm{N}$ incorporation in leaf and root growth zones of Lolium perenne after defoliation: assessment by ${ }^{13} \mathrm{C}$ and ${ }^{15} \mathrm{~N}$ steady-state labelling. Plant, Cell and Environment 20: 37-46.

Donaghy, D.J. 1998. Improving the production and persistence of temperate pasture species in subtropical dairy regions of Australia. $\mathrm{PhD}$ thesis. University of New England.

Donaghy, D.J.; Fulkerson, W.J. 1997. The importance of water-soluble carbohydrate reserves on regrowth and root growth of Lolium perenne (L.). Grass and Forage Science 52: 401-407.

Donaghy, D.J.; Fulkerson, W.J. 1998. Priority for allocation of water-soluble carbohydrate reserves during regrowth of Lolium perenne. Grass and Forage Science 53: 211-218.

Fulkerson, W.J.; Donaghy, D.J. 2001. Plant-soluble carbohydrate reserves and senescence - key criteria for developing an effective grazing management system for ryegrass-based pastures: a review. Australian Journal of Experimental Agriculture 41: 261-275.

Fulkerson, W.J.; Slack, K. 1994. Leaf number as a criterion for determining defoliation time for Lolium perenne. 1. Effect of water-soluble carbohydrates and senescence. Grass and Forage Science 49: 373-377.

Grant, S.A.; Barthram, G.T.; Torvell, L. 1981. Components of regrowth in grazed and cut Lolium perenne swards. Grass and Forage Science 36: 155168.

Kemp, P.D.; Matthew, C.; Lucas, R.J. 2000. Pasture species and cultivars. pp. 83-100. In: New Zealand Pasture and Crop Science. Eds. White, J.; Hodgson, J. Oxford University Press, Auckland.

Koch, K.E. 1996. Carbohydrate-modulated gene expression in plants. Annual Review of Plant
Physiology and Plant Molecular Biology 47: 509540.

Lee, J.M.; Donaghy, D.J.; Sathish, P.; Roche, J.R. 2009. Interaction between water-soluble carbohydrate reserves and defoliation severity on the regrowth of perennial ryegrass (Lolium perenne L.)-dominant swards. Grass and Forage Science 64: 266-275.

Lee, J.M.; Puthigae, S.; Donaghy, D.J.; Roche, J.R. 2010a. Plants modify biological processes to ensure survival following carbon depletion: A Lolium perenne model. PLOS ONE: In Press.

Lee, J.M.; Roche, J.R.; Donaghy, D.J.; Thrush, A.; Sathish, P. 2010b. Validation of reference genes for quantitative RT-PCR studies of gene expression in perennial ryegrass (Lolium perenne L.). BMC Molecular Biology 11: 8.

Morvan-Bertrand, A.; Boucaud, J.; Le Saos, J.; Prud'homme, M.P. 2001. Roles of the fructans from leaf sheaths and from the elongating leaf bases in the regrowth following defoliation of Lolium perenne L. Planta 213: 109-120.

Morvan-Bertrand, A.; Boucaud, J.; Prud'homme, M.P. 1999. Influence of initial levels of carbohydrates, fructans, nitrogen and soluble proteins on regrowth of Lolium perenne L. cv. Bravo following defoliation. Journal of Experimental Botany 50: 1817-1826.

Nagaraj, V.J.; Altenbach, D.; Galati, V.; Luscher, M.; Meyer, A.D.; Boller, T.; Wiemken, A. 2004. Distinct regulation of sucrose:sucrose-1-fructosyltransferase (1-SST) and sucrose:fructan-6-fructosyltransferase (6-SFT), the key enzymes of fructan synthesis in barley leaves: 1-SST as the pacemaker. New Phytologist 161: 735-748.

Parsons, A.J.; Chapman, D.F. 2000. The principles of pasture growth and utilization. pp. 31-89. In: Grass: Its Production and Utilization. Ed. Hopkins, A. Blackwell Science Ltd., Oxford.

Parsons, A.J.; Penning, P.D. 1988. The effect of the duration of regrowth on photosynthesis, leaf death and the average rate of growth in a rotationally grazed sward. Grass and Forage Science 43: 15-27.

Prud'homme, M.; Gonzalez, B.; Billard, J.; Boucaud, J. 1992. Carbohydrate content, fructan and sucrose enzyme activities in roots, stubble and leaves of ryegrass (Lolium perenne L.) as affected by source/ sink modification after cutting. Journal of Plant Physiology 140: 282-291.

Rasmussen, S.; Parsons, A.J.; Xue, H.; Newman, J.A. 2009. High sugar grasses - harnessing the benefits of new cultivars through growth management. Proceedings of the New Zealand Grassland Association 71: 167-175.

Robson, M.J. 1973. The growth and development of simulated swards of perennial ryegrass. I. Leaf growth 
and dry weight change as related to the ceiling yield of a seedling sward. Annals of Botany 37: 487-500.

Rozen, S.; Skaletsky, H.J. 2000. Primer3 on the WWW for general users and for biologist programmers. pp. 365-386. In: Methods in Molecular Biology: Bioinformatics Methods and Protocols. Eds. Misener, S.; Krawetz, S.A. Humana Press, Totowa.

Smith, D. 1969. Removing and analysing total nonstructural carbohydrates from plant tissue. pp. 1-11. In: Research Report Wisconsin Agricultural Experimental Station, Madison.

Turner, L.R.; Donaghy, D.J.; Lane, P.A.; Rawnsley, R.P. 2006. Effect of defoliation management based on leaf stage on perennial ryegrass (Lolium perenne L.), prairie grass (Bromus willdenowii L.) and cocksfoot (Dactylis glomerata L.) under dryland conditions. 1. Regrowth, tillering and water-soluble carbohydrate concentration. Grass and Forage Science 61: 164174.

VSN International Ltd. 2008. GenStat Release 11 Reference Manual, Part 3 Procedure Library PL19. VSN International Limited, Hemel Hempstead. 
